\title{
Adenylyl cyclase activity in human decidua and myometrium during pregnancy and labour
}

\author{
K. Miyazaki, N. Tanaka, S. Kawakami and H. Okamura \\ Department of Obstetrics and Gynaecology, Kumamoto University School of Medicine, 1-1-1 Honjo, \\ Kumamoto 860, Japan
}

\begin{abstract}
Adenylyl cyclase activity was studied in human decidua and myometrium in early pregnancy and at term before and after the onset of labour. Decidual basal, prostaglandin-, catecholamine- and forskolin-stimulated adenylyl cyclase activities at term before the onset of labour were significantly lower than those in early pregnancy. After the onset of labour at term, decidual basal, prostaglandin-, catecholamine-, NaF- and forskolin-stimulated adenylyl cyclase activities significantly increased compared with those at term before the onset of labour. Myometrial prostaglandin- and catecholamine-stimulated activities did not alter during pregnancy, except for basal and forskolin-stimulated activity. Myometrial basal, prostaglandin-, catecholamine-, NaF- and forskolin-stimulated activities at term showed no change after the onset of labour. At term, before the onset of labour, myometrial basal, prostaglandin, catecholamine-, NaF- and forskolin-stimulated activities were the same as those in the decidua. However, after the onset of labour at term, decidual basal and the stimulated activities were significantly higher than those in the myometrium. These results suggest that decidual prostaglandin- and catecholamine-stimulated adenylyl cyclase may play an important role in the initiation or maintenance of human labour or in both processes.
\end{abstract}

\section{Introduction}

Despite extensive research efforts spanning several decades, the basic mechanism of initiation of human parturition remains unknown. It is well established that prostaglandins (PGs) of the $\mathrm{E}$ and $\mathrm{F}$ series play a major role in the mechanism of the onset of labour. During pregnancy, the major sites of PG generation include the fetal membranes, especially the amnion, and the decidua. The chorion and the decidua contain enzymes capable of completely metabolizing PGs produced by the amnion (Casey et al., 1989; Skinner and Challis, 1985). Amnion PGE $_{2}$ produced on the fetal side of the membranes is metabolized before passage through the membrane to the myometrium (Nakla et al., 1986; Bennett et al., 1990). Only a small percentage of the PGs produced by the amnion can cross the membranes and reach the myometrium. Therefore, it is postulated that uterotonic PGs produced by the decidua have an important role in the control of the onset of labour.

There is much evidence to support the view that the rate of PG synthesis is controlled by several factors such as protein kinase C (Zakar and Olson, 1988) and phospholipase $A_{2}$ (Wilson, 1990). In in vitro studies using decidua tissue or isolated cells, increases in PG production have been reported in response to a variety of hormones and regulatory factors including catecholamines (Warrick et al., 1985; Hassan et al., 1992), oxytocin (Fuchs et al., 1982), histamine (Smith et al., 1988), epidermal growth factor (Mitchell, 1991) and the cytokines interleukin 1 (Romero et al., 1989a) and tumour necrosis factor (Romero et al., 1989b).
The output of PGs from the decidua is also influenced by modulators of cAMP-dependent protein kinase. The decidua contain an active adenylyl cyclase system, which can be stimulated with $\mathrm{PGE}_{1}$ and $\mathrm{PGE}_{2}$ and with $\beta$ agonists such as isoproterenol, forskolin and cholera toxin (Whitsett and Johnson, 1979; Di Renzo et al., 1984; Warrick et al., 1985). The effects of forskolin and cholera toxin on cAMP output by amnion and decidual cells were associated temporally with an increase in the output of PG by the decidua. The effects of activators of adenylyl cyclase on PG biosynthesis could be mimicked by addition of dibutyryl cAMP (dbcAMP) or phosphodiesterase inhibitors such as methylxanthine. These reports suggest that decidual adenylyl cyclase activities, which can control production of PGs in the decidua, are affected by PGs and catecholamines produced in the decidua or amnion via an autocrine or paracrine mechanism and that they may play an important role in the onset of labour.

In human myometrium, $\beta$-adrenoceptor agonists and $\mathrm{PGE}_{2}$ receptor agonists stimulate adenylyl cyclase, increasing cAMP formation with subsequent myometrial relaxation (Litime ef al., 1989; Word et al, 1993). Litime et al. (1989) described a decrease in isoproterenol-stimulated adenylyl cyclase activity in human myometrium at between 32 and 40 weeks of gestation, but there was no change in forskolin-stimulated activity. The concentration of PGE receptors was lower in pregnant uteri at term than in non-pregnant uteri (Adelantado et al., 1988).

On the basis of these data, an investigation was conducted to evaluate the possibility that there are some changes in decidual and myometrial PG- and catecholamine-stimulated 
adenylyl cyclase activities during pregnancy and after the onset of labour. PG- and catecholamine-stimulated adenylyl cyclase activities were measured in the decidua and myometrium in early pregnancy and at term before and after the onset of labour.

\section{Materials and Methods}

\section{Chemicals}

$\left[2,8-^{3} \mathrm{H}\right] \mathrm{cAMP}\left(30-34 \mathrm{Ci} \mathrm{mmol}^{-1}\right)$ was obtained from New England Nuclear (Boston, MA); L-isoproterenol, L-adrenaline, L-noradrenaline, $\mathrm{PGE}_{2}, \mathrm{PGF}_{2, \boldsymbol{a}} \mathrm{NaF}, \mathrm{cAMP}, \mathrm{ATP}$ and GTP were from Sigma Chemical Co. (St Louis, MO); and RPMI 1640 medium was from GIBCO Laboratories (Grand Island, NY). Forskolin was kindly provided by Hoechst AG (Frankfurt) through Nippon Kayaku Co. Ltd (Tokyo). Other chemicals were of analytical grade.

\section{Tissue collection and preparation}

All tissue samples were collected after obtaining the informed written consent of the patients. The patients were 27-46 years old. Decidua vera tissue was dissected from the chorion. Decidua vera in early pregnancy (at 5-10 weeks of gestation) was obtained from six women, who requested termination of pregnancy or who were undergoing hysterectomy owing to medical indication such as carcinoma in situ or microinvasive carcinoma of the uterine cervix. Decidua vera at term (37-40 weeks of gestation) was obtained by Caesarean section from seven women before the onset of labour and from eight women after the onset of labour. Myometrial samples in early pregnancy were obtained from five women who were undergoing hysterectomy because of medical indication such as described above, and these tissues were taken from the lower uterine segment. Myometrial samples at term were obtained by Caesarean section from five women before the onset of labour and from five women after the onset of labour, and these tissues were removed from the upper border of the uterine incision at the lower uterine segment during Caesarean section.

Immediately after collection, the samples were transported to the laboratory in RPMI 1640 medium at $37^{\circ} \mathrm{C}$. After removal of blood clots and mucus, tissue samples were excised. Decidual tissues (20-100 mg wet mass) were homogenized with 30 volumes of a homogenizing solution containing $2 \mathrm{mmol}$ Tris- $\mathrm{HCl} \mathrm{^{-1 }}$, in a glass homogenizer on ice. Myometrial tissues (150-250 mg wet mass) were homogenized with three $10 \mathrm{~s}$ bursts at a setting of 5 in a Polytron (Kinemaica, Steinhofhald, Switzerland) in 10 volumes of the same homogenizing solution and were subsequently homogenized in a glass homogenizer on ice.

A part of each tissue sample obtained was saved for histological examination. Histological study showed that decidual samples were free of trophoblastic elements and contained no myometrium, and samples of myometrium did not contain decidual tissue.

\section{Determination of adenylyl cyclase activity}

The assay was performed within $1 \mathrm{~h}$ after removal, without freezing, of the tissue. The adenylyl cyclase assay was a modification of the procedure described by Zatz et al. (1976). The standard assay system (final volume $60 \mu \mathrm{l}$ ) for measurement of adenylyl cyclase activity contained $80 \mathrm{mmol}$ Tris$\mathrm{HCl} \mathrm{l}^{-1}\left(\mathrm{pH} 7.4\right.$ ), $1 \mathrm{mmol} \mathrm{MgSO}_{4} \mathrm{l}^{-1}, 0.8 \mathrm{mmol}$ EGTA l ${ }^{-1}$, $10 \mathrm{mmol}$ theophylline $\mathrm{I}^{-1}, 0.25 \mathrm{mmol}$ ATP $\mathrm{I}^{-1}, 0.01 \mathrm{mmol}$ GTP $1^{-1}$, tissue homogenate $(25-60 \mu \mathrm{g}$ protein) and agents, such as catecholamines, PGs and forskolin, at the final concentrations indicated. PGs and forskolin were initially dissolved in absolute ethanol to achieve a concentration of $10 \mathrm{mmol} \mathrm{l}^{-1}$, and subsequent solutions were prepared using water as the solvent. Basal activity was determined in the presence of an equal amount of ethanol. Results were expressed in pmol cAMP generated $\mathrm{mg}^{-1}$ protein $\min ^{-1}$. After incubation for $10 \mathrm{~min}$ at $30^{\circ} \mathrm{C}$, the reaction was terminated by placing each tube in boiling water for $2 \mathrm{~min}$.

Both the basal and stimulated adenylyl cyclase activities were found to be proportional to the protein content in the tissue homogenate $(10-200 \mu \mathrm{g})$ and also to the time $(0-25 \mathrm{~min})$ at $30^{\circ} \mathrm{C}$. Optimal conditions for measuring stimulated adenylyl cyclase activity were compared during pregnancy. Maximal stimulation of decidual adenylyl cyclase activity during pregnancy was observed at concentrations of approximately $30 \mu \mathrm{mol} 1^{-1}$ for $\mathrm{PGE}_{2}, \mathrm{PGF}_{2 \alpha}$ and catecholamines, $10 \mathrm{mmol} \mathrm{l}^{-1}$ for $\mathrm{NaF}$ and $100 \mu \mathrm{mol} \mathrm{l} \mathrm{l}^{-1}$ for forskolin (Tanaka et al., 1993). The above concentrations of these agents were therefore used for all subsequent assays.

The amount of cAMP produced was determined by the method of Brown et al. (1971), with some modification using the protein binding assay. The binding reagent was prepared from bovine adrenal extracts. The sensitivity of this assay was $0.1-40$ pmol per tube. Quadruplicate assays of adenylyl cyclase activity were made for each value determined.

\section{Protein assay}

The amount of protein was determined by the method of Lowry et al. (1951), using BSA as a standard.

\section{Statistical analyses}

Data are expressed as means \pm SEM. Statistical comparisons were performed using analysis of variance and Scheffe's test. The level of significance was chosen as $P<0.05$.

\section{Results}

Immediately after homogenizing the tissue samples, the cAMP content of the decidua and myometrium was measured. CAMP content varied widely among the tissue samples during pregnancy. CAMP content in the myometrium was slightly lower than that in the decidua (Tables 1 and 2). In the decidua, cAMP content at term before the onset of labour was low compared with that in early pregnancy at 5-10 weeks of gestation, although the difference was not significant. cAMP content at term (37-40 Downloaded from Bioscientifica.com at 04/26/2023 10:52:40AM 
Table 1. Adenylyl cyclase activities stimulated by prostaglandins, catecholamines, NaF and forskolin in human decidua during pregnancy and labour

\begin{tabular}{|c|c|c|c|c|c|c|c|c|c|}
\hline & \multirow{2}{*}{$\begin{array}{l}\text { Onset } \\
\text { of } \\
\text { labour }\end{array}$} & \multirow[b]{2}{*}{$n$} & \multirow[b]{2}{*}{$\begin{array}{c}\text { Basal } \\
\text { activity }\end{array}$} & \multicolumn{6}{|c|}{ Stimulated activity (pmol cAMP formed $\mathrm{mg}^{-1}$ protein $\min ^{-1}$ ) } \\
\hline & & & & $\begin{array}{c}\mathrm{PGE}_{2} \\
\left(30 \mu \mathrm{mol} \mathrm{l}^{-1}\right)\end{array}$ & $\begin{array}{c}\text { PGF }_{2 k} \\
\left(30 \mu \mathrm{mol} \mathrm{l}^{-1}\right)\end{array}$ & $\begin{array}{l}\text { Isoproterenol } \\
\left(30 \mu \mathrm{mol} 1^{-1}\right)\end{array}$ & $\begin{array}{c}\text { Adrenaline } \\
\left(30 \mu \mathrm{mol} \mathrm{l}^{-1}\right)\end{array}$ & $\begin{array}{c}\mathrm{NaF} \\
\left(10 \mathrm{mmol}^{-1}\right)\end{array}$ & $\begin{array}{c}\text { Forskolin } \\
\left(100 \mu \mathrm{mol} 1^{-1}\right)\end{array}$ \\
\hline \multirow[t]{2}{*}{ Early pregnancy } & $(-)$ & 6 & 2.67 & 5.60 & 3.94 & 2.97 & 3.00 & N.D. & 30.5 \\
\hline & & & \pm 0.42 & \pm 0.56 & \pm 0.42 & \pm 0.36 & \pm 0.34 & & \pm 6.0 \\
\hline \multirow[t]{2}{*}{ Term } & $(-)$ & 7 & 1.15 & 1.59 & 1.02 & 1.20 & 1.05 & 3.05 & 12.6 \\
\hline & & & $\pm 0.28^{b}$ & $\pm 0.12^{\mathrm{a}}$ & $\pm 0.28^{a}$ & $\pm 0.30^{\mathrm{b}}$ & $\pm 0.20^{b}$ & \pm 0.51 & $\pm 1.80^{\mathrm{b}}$ \\
\hline \multirow[t]{2}{*}{ Term } & $(+)$ & 8 & 3.50 & 8.26 & 5.93 & 6.63 & 7.39 & 17.0 & 37.8 \\
\hline & & & $\pm 0.29^{c}$ & $\pm 0.54^{\mathrm{c}}$ & $\pm 0.60^{c}$ & $\pm 0.48^{c}$ & $\pm 0.58^{c}$ & $\pm 0.90^{\circ}$ & $\pm 2.00^{\circ}$ \\
\hline
\end{tabular}

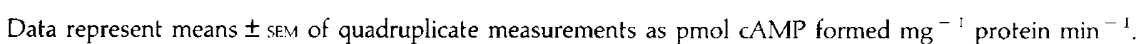

N.D.: not determined.

${ }^{a}$ Significantly different from early pregnancy $(P<0.01)$; ${ }^{b}$ significantly different from early pregnancy $(P<0.05)$; ${ }^{c}$ significantly different from before the onset of pregnancy at term $(P<0.001)$.

Table 2. Adenylyl cyclase activities stimulated by prostaglandins, catecholamines, $\mathrm{NaF}$ and forskolin in human myometrium during pregnancy and labour

\begin{tabular}{|c|c|c|c|c|c|c|c|c|c|}
\hline & \multirow{2}{*}{$\begin{array}{c}\text { Onset } \\
\text { of } \\
\text { labour }\end{array}$} & \multirow[b]{2}{*}{$n$} & \multirow[b]{2}{*}{$\begin{array}{l}\text { Basal } \\
\text { activity }\end{array}$} & \multicolumn{6}{|c|}{ Stimulated activity (pmol cAMP formed $\mathrm{mg}^{-1}$ protein $\min ^{-1}$ ) } \\
\hline & & & & $\begin{array}{c}\mathrm{PGE}_{2} \\
\left(30 \mu \mathrm{mol} \mathrm{I}^{-1}\right)\end{array}$ & $\begin{array}{c}\mathrm{PGF}_{2 u} \\
\left(30 \mu \mathrm{mol} \mathrm{1}^{-1}\right)\end{array}$ & $\begin{array}{l}\text { Isoproterenol } \\
\left(30 \mu \mathrm{mol} \mathrm{l} l^{-1}\right)\end{array}$ & $\begin{array}{l}\text { Adrenaline } \\
\left(30 \mu \mathrm{mol} 1^{-1}\right)\end{array}$ & $\begin{array}{c}\mathrm{NaF} \\
\left(10 \mathrm{mmol}^{-1}\right)\end{array}$ & $\begin{array}{c}\text { Forskolin } \\
\left(100 \mu \mathrm{mol} \mathrm{I}^{-1}\right)\end{array}$ \\
\hline \multirow[t]{2}{*}{ Early pregnancy } & $(-)$ & 5 & 0.80 & 2.44 & 1.52 & 1.32 & 1.37 & N.D. & 10.80 \\
\hline & & & \pm 0.07 & \pm 0.11 & \pm 0.12 & \pm 0.16 & \pm 0.10 & & \pm 2.10 \\
\hline \multirow[t]{2}{*}{ Term } & $(-)$ & 5 & 1.62 & 2.79 & 1.96 & 2.13 & 2.11 & 7.05 & 19.11 \\
\hline & & & $\pm 0.23^{\mathrm{a}}$ & \pm 0.22 & \pm 0.25 & \pm 0.34 & \pm 0.35 & \pm 0.72 & $\pm 1.41^{\mathrm{a}}$ \\
\hline \multirow[t]{2}{*}{ Term } & $(+)$ & 5 & 1.55 & 2.96 & 1.83 & 1.73 & 2.01 & 8.70 & 21.10 \\
\hline & & & \pm 0.06 & \pm 0.34 & \pm 0.31 & \pm 0.32 & \pm 0.17 & \pm 0.44 & \pm 1.02 \\
\hline
\end{tabular}

Data represent means \pm SEM of quadruplicate measurements as pmol CAMP formed $\mathrm{mg}^{-1}$ protein $\mathrm{min}^{-1}$.

N.D.: not determined.

${ }^{a}$ Significantly different $(P<0.05)$ from value in early pregnancy.

weeks of gestation) after the onset of labour was higher than that before the onset of labour, although the difference was not significant (Table 1 ).

In the decidua, basal adenylyl cyclase activity before the onset of labour at term was significantly lower $(P=0.02)$ than that in early pregnancy. $\mathrm{PGE}_{2}$ and $\mathrm{PGF}_{2 u}$-stimulated activities were significantly lower $(P=0.0008$ and 0.008 , respectively) before the onset of labour at term than those in early pregnancy. Isoproterenol-, adrenaline- and forskolin-stimulated activities were also significantly lower $(P=0.046,0.037$ and 0.030 , respectively) before the onset of labour at term compared with those in early pregnancy. After the onset of labour at term, basal, $\mathrm{PGE}_{2^{-}}, \mathrm{PGF}_{2 u^{-}}$, isoproterenol-, adrenaline-, $\mathrm{NaF}-$ and forskolin-stimulated activities were significantly increased $(P=0.00055,0.00001,0.00008,0.00002,0.00001,0.00009$ and 0.005 , respectively) by $3.0,5.2,5.8,5.5,7.0,5.6$ and 3.0 times, respectively, compared with those before the onset of labour at term (Table 1).

In the myometrium, basal and forskolin-stimulated activities at term before the onset of labour were significantly $(P=0.013$ and 0.016 , respectively) higher than those in early pregnancy.
However, activities stimulated by all other agents studied before the onset of labour at term were similar to those in early pregnancy. Myometrial basal and stimulated adenylyl cyclase activities after the onset of labour at term were not significantly different from those before the onset of labour at term (Table 2).

The adenylyl cyclase activities in the decidua were compared with those in the myometrium. In early pregnancy, basal, $\mathrm{PGE}_{2^{-}}, \mathrm{PGF}_{2 a^{-}}$, adrenaline- and forskolin-stimulated activities in the decidua were significantly $(P=0.003,0.002$, $0.003,0.007$ and 0.035 , respectively) higher than those in the myometrium. However, before the onset of labour at term, $\mathrm{PGE}_{2^{-}}, \mathrm{PGF}_{2 a^{-}}$, isoproterenol-adrenaline-, NaF- and forskolinstimulated activity in the decidua were significantly $(P=0.004,0.027,0.056,0.034,0.006$ and 0.0034 , respectively) lower than those in the myometrium. After the onset of labour at term, basal, $\mathrm{PGE}_{2^{-}}, \mathrm{PGF}_{2 a^{-}}$, isoproterenol-, adrenaline-, NaF- and forskolin-stimulated activities were found to be significantly higher in the decidua than in the myometrium $(P=0.002,0.001,0.002,0.001,0.002,0.001$ and 0.001 , respectively) (Tables 1 and 2). 


\section{Discussion}

The function of the decidua has not been clearly defined but suggested functions include a role in the implantation and nutrition of the blastocyst, the restriction of the invading trophoblast, and immunological separation of maternal and fetal tissues. Since the decidua is well vascularized and lies adjacent to the myometrium, the release of prostaglandins from the decidua to the myometrium is important in the initiation and maintenance of labour. However, the endocrine/paracrine/ autocrine and biochemical mechanisms regulating decidual PG production during pregnancy and normal labour are poorly understood.

Whitsett and Johnson (1979) demonstrated that there is adenylyl cyclase activity in human decidua parietalis, and showed that adenylyl cyclase was stimulated by $\mathrm{PGE}_{1}$ and $\mathrm{PGE}_{2}$. In the study reported here significant quantities of $\mathrm{PGE}_{2^{-}}$ and $\mathrm{PGF}_{2 a}$-stimulated adenylyl cyclase activities were present and caused marked alterations in human decidua after the onset of labour. After the onset of labour at term, $\mathrm{PGE}_{2^{-}}$and $\mathrm{PGF}_{2 a}$-stimulated adenylyl cyclase activities in the decidua significantly increased 5.2 and 5.8 times, respectively, compared with those before the onset of labour at term. However, decidual basal, $\mathrm{PGE}_{2}$ - and $\mathrm{PGF}_{2{ }^{-}}$-stimulated adenylyl cyclase activities before the onset of labour were significantly lower than those in early pregnancy.

The tissue concentration of $\mathrm{PGE}_{2}$ and $\mathrm{PGF}_{2 a}$ in the decidua during the first trimester was significantly lower than that in the endometrium. The concentration of $\mathrm{PGE}_{2}$ in the decidua was higher at term than during the first trimester. During labour there was a significant rise in the concentration of $\mathrm{PGE}_{2}$ in the decidua, and this was true to a lesser extent in the myometrium and amnion (Willman and Collins, 1976). The specific changes in PG-stimulated adenylyl cyclase activities appear to coincide with changes in decidual tissue content of PGs during pregnancy and labour. This finding suggests that decidual cells can respond to PGs by increasing cAMP production, and that increased tissue content of CAMP and the response of adenylyl cyclase to PGs cooperatively may play an important role in production of PGs in the decidua via an autocrine or paracrine mechanism. Production of PGs in the decidua can be amplified by PG-stimulated adenylyl cyclase. The decidua may play a role in amplifying production of PGs.

Human decidua contains many different cell populations. As pregnancy progresses, the glands rapidly regress and by mid-gestation only isolated gland fragments remain (Pijnenborg et al., 1980). Forty-seven per cent of decidual cells at term are of bone marrow origin (Vince et al., 1990). Smith and Kelly (1988) demonstrated that the main source of PGF and $\mathrm{PGE}_{2}$ in the decidua of early pregnancy is the glandular cells. Nowitz et al. (1991) reported that the PG production within the human decidua at term is mainly from the population of macrophage-like cells. Further study is required to clarify which decidual cell subpopulation, i.e. the glandular, stromal or macrophage-like cells from human decidua, is responsible for $\mathrm{PG}$ and $\mathrm{CAMP}$ production at term. However, decidual $P G$ production stimulated by $P G s$ produced in the decidua may play an important physiological role, such as the initiation and maintenance of human labour via an autocrine or paracrine mechanism.
It was assumed, on the basis of the decidual adenylyl cyclase activity data, that myometrial PG-stimulated adenylyl cyclase activities increase after the onset of labour. However, it was surprising that myometrial basal and stimulated activities did not increase after the onset of labour. This result indicates that human myometrial adenylyl cyclase may not play an important role in the onset of human labour.

Warrick et al. (1985) demonstrated increased adenylyl cyclase activity and PG output in human decidual cells in response to the $\beta$-adrenergic agonists, cholera toxin and forskolin. Hassan et al. (1992) reported that human decidua contained an intact $\beta$-adrenergic system that produced $\mathrm{PGE}_{2}$ and $\mathrm{PGF}_{2 u}$ in response to catecholamine or forskolin. In human myometrium, adrenaline and noradrenaline also stimulate synthesis of $\mathrm{PGE}_{2}$ and $\mathrm{PGF}_{2 u^{\prime}}$ as well as that of 6-keto-PGF (Quaas and Zahradnik, 1985).

It is known that the concentration of catecholamines increases in amniotic fluid during late pregnancy, suggesting progressive fetal adrenergic maturation (Divers et al., 1981). Zuspan (1970) found that an increase in urinary excretion of noradrenaline was associated with labour. Significant quantities of catecholamines are present in the human uterus during pregnancy (Cha et al., 1964). In the present study decidual isoproterenol- and adrenaline-stimulated adenylyl cyclase activities were lower at term than in early pregnancy. After the onset of labour, these activities were increased by 5.8 and 5.5 times, respectively, compared with those before the onset of labour. However, isoproterenol- and adrenaline-stimulated activities did not alter during pregnancy and labour in the myometrium. These data suggest that human decidua and myometrium possess a $\beta$-adrenergic receptor-adenylyl cyclase system but that only the decidual system is stimulated after the onset of labour. It is possible that decidual adenylyl cyclase activity stimulated by catecholamines in amniotic fluid increases production of PGs in the decidua and plays a role in the initiation or maintenance of labour or in both processes. In addition, Warrick et al. (1985) showed that catecholamine stimulated PGE and PGF output from the amnion. Therefore, another possible explanation for the link between catecholamine in amniotic fluid and decidual production of PGs is that catecholamine in amniotic fluid increases production of PGs in the amnion, and that PGs produced in the amnion stimulate decidual production of PGs. This phenomenon could be important as the first step in decidual production of PGs.

In the myometrium, basal and forskolin-stimulated adenylyl cyclase activities before the onset of labour at term increased by two times compared with those in early pregnancy. However, basal and forskolin-stimulated adenylyl cyclase activities before the onset of labour at term decreased by $50 \%$ compared with those in early pregnancy in the decidua. These data suggest that the regulation mechanism of adenylyl cyclase in the myometrium may be different from that in the decidua.

In summary, specific alterations in adenylyl cyclase activity were shown to occur in human decidua during pregnancy and after the onset of labour. These data suggest that decidual PG- and catecholamine-stimulated adenylyl cyclase may play an important role in the initiation or maintenance of human labour or in both processes and in production of PGs in human decidua. Further studies are needed to clarify the precise Downloaded from Bioscientifica.com at 04/26/2023 10:52:40AM 
mechanisms involved and the physiological roles played by decidual and myometrial changes in adenylyl cyclase activity.

\section{References}

Adelantado JM, Lopez Bernal A and Turnbull AC (1988) Topographical distribution of prostaglandin E receptors in human myometrium British journal of Obstetrics and Gynaesology 95 348-353

Bennett PR, Chamberlain G, Patel L, Edler MG and Myatt L (1990) Mechanism of parturition: the transfer of prostaglandin $\mathrm{E}_{2}$ and 5-hydroxy-casatetraenoic acid across fetal membranes American Journal of Obstetrics and Gynecology $162683-687$

Brown BL, Albano JDM, Ekins RP and Sgherzi AM (1971) A simple and sensitive saturation assay method for the measurement of adenosine $3^{\prime}: 5^{\prime}$-cyclic monophosphate Biochemical Journal 121 561-562

Casey ML, Delgadillo M, Cox KA, Niesert S and MacDonald PC (1989) Inactivation of prostaglandins in human decidua parietalis tissue: substrate specificity of prostaglandin dehydrogenase American Journal of Obstetrics and Gynecology 160 3-7

Cha K-S, Lee W-C, Rudzik A and Miller JW (1964) A comparison of the catecholamine concentrations of uteri from several species and the alterations which occur during pregnancy Journal of Pharmacology and Experimental Therapeutics 148 9-13

Di Renzo GC, Venincasa MD and Bleasdale JE (1984) The identification and characterization of $\beta$-adrenergic receptors in human amnion tissue American Journal of Obstetrics and Gynecology 148 398-465

Divers WA, Jr, Wilkes MM, Babaknia A and Yen SSC (1981) An increase in catecholamines and metabolites in the amniotic fluid compartment from middle to late gestation American Journal of Obstetrics and Gynecology 139 483-486

Fuchs A-R, Fuchs F and Husslein $P$ (1982) Oxytocin receptors and parturition: a dual role for oxytocin in the initiation of labor Science 215 1396-1398

Hassan N, Moore RM and Moore JJ (1992) The adenylate cyclase system and prostaglandin production in human decidua parietalis Placenta 13 241-253

Litime M, Pointis G, Breuiller M, Cabrol D and Ferre F (1989) Disappearance of $\beta$-adrenergic response of human myometrial adenylate cyclase at the end of pregnancy Journal of Clinical Endocrinology and Metabolism 68 I-6

Lowry OH, Rosebrough NJ, Farr AL and Randall RJ (1951) Protein measurement with the Folin phenol reagent Journal of Biological Chemistry 193 265-276

Mitchell MD (1991) The regulation of decidual prostaglandin biosynthesis by growth factors, phorbol esters and calcium Biology of Reproduction 44 $871-874$

Nakla S, Skinner K, Mitchell BF and Challis JRG (1986) Changes in prostaglandin transfer across human fetal membranes obtained after spontaneous labor American Journal of Obstetrics and Gynecology 155 1337-1341

Norwitz ER, Starkey PM, Lopez Bernal A and Turnbull AC (1991) Identification by flow cytometry of the prostaglandin-producing cell populations of term human decidua Journal of Endocrinology 131 327-334
Pijnenborg R, Dixon G, Robertson WB and Brosense I (1980) Trophoblastic invasion of human decidua from 8-18 weeks of pregnancy Placenta 1 3-19

Quaas $L$ and Zahradnik HP (1985) The effects of $\alpha$ - and $\beta$-adrenergic stimulation on contractility and prostaglandin (prostaglandins $\mathrm{E}_{2}$ and $\mathrm{F}_{2 \alpha}$ and 6-ketoprostaglandin $\mathrm{F}_{1 n}$ ) production of pregnant human myometrial strips American Journal of Obstetrics and Gynecology 152 852-856

Romero R, Durum S, Dinarello C, Oyarzun E, Hobbins JC and Mitchell MD (1989a) Interleukin 1 stimulates prostaglandin biosynthesis by human amnion Prostaglandins 37 13-22

Romero R, Mazor M, Wu YK, Avila C, Oyarzun E and Mitchell MD (1989b) Bacterial endotoxin and tumor necrosis factor stimulate prostaglandin production by human decidua Prostaglandins Leukotriens and Essential Fatty Acids 37 183-186

Skinner KA and Challis JRG (1985) Changes in the synthesis and metabolism of prostaglandins by human fetal membranes and decidua at labor American Journal of Obstetrics and Gynecology 151 519-52.3

Smith SK and Kelly RW (1988) The release of $\mathrm{PGF}_{2 t}$ and PGE 2 from separated cells of human endometrium and decidua Prostaglandins Leukotriens and Essential Fatty Acids 33 91-96

Tanaka N, Miyazaki K, Tashiro H, Mizutani H and Okamura H (1993) Changes in adenylyl cyclase activity in human endometrium during the menstrual cycle and in human decidua during pregnancy Journal of Reproduction and Fertility $9733-39$

Vince GS, Starkey PM, Jackson MC, Sargent IL and Redman CWG (1990) Flow cytometric characterization of cell populations in human pregnancy decidua and isolation of decidual macrophages Journal of Immunological Methods 132 181-189

Warrick C, Skinner K, MitcheII BF and Challis JRG (1985) Relation between cyclic adenosine monophosphate and prostaglandin output by dispersed cells from human amnion and decidua American Journal of Obstetrics and Gynecology 153 66-71

Whitsett JA and Johnson CL (1979) Adenylate cyclase from human decidua parietalis American Journal of Obstetrics and Gynecology 133 479-483

Willman EA and Collins WP (1976) Distribution of prostaglandin $E_{2}$ and $F_{2 n}$ within the foetoplacental unit throughout human pregnancy Journal of Endocrinology 69 413-419

Wilson T (1990) Phospholipase in human parturition Reproduction. Fertility and Development 2 511-521

Word RA, Kamm KE and Casey ML (1993) Contractile effects of prostaglandins, oxytocin, and endothelin- 1 in human myometrium in vitro: refractoriness of myometrial tissue of pregnant women to prostaglandins $\mathrm{E}_{2}$ and $\mathrm{F}_{2 u}$ Journal of Clinical Endocrinology and Metabolism 75 1027-1032

Zakar T and Olson DM (1988) Stimulation of human amnion prostaglandin $E_{2}$ production by activators of protein kinase $C$ Journal of Clinical Endocrinology and Metabolism $67915-923$

Zatz M, Kebabian JW, Romero JA, Lefkowitz RJ and Axelrod J (1976) Pineal beta adrenergic receptor: correlation of binding of ${ }^{3} \mathrm{H}$-I-alprenolol with stimulation of adenylate cyclase Journal of Pharmacology and Experimental Therapeutics $196714-722$

Zuspan FP (1970) Urinary excretion of epinephrine and norepinephrine during pregnancy Journal of Clinical Endocrinology and Metabolism 30 357-360 